\title{
KRISIS HIPERTENSI
}

\author{
Hypertensive Crises
}

\section{Risa Herlianita}

\author{
Program Studi Diploma III Keperawatan Fakultas Ilmu Kesehatan Universitas Muhammadiyah Malang \\ Jl. Bendungan Sutami 188A Malang 65145 \\ Email: ns.risa.liani@gmail.com
}

\begin{abstract}
ABSTRAK
Hipertensi merupakan penyebab utama kematian dan menjadi faktor risiko utama untuk jantung, otak, penyakit ginjal dan vaskular. Hipertensi yang terkontrol akan menurunkan komplikasi akibat kerusakan organ akhir. Komite Nasional 7 (JNC 7) pada pencegahan, deteksi, evaluasi dan pengobatan tekanan darah, tinggi 2003 derajat hipertensi dapat diklasifikasikan ke dalam pra-hipertensi (120-139/80-89), hipertensi tahap 1 (140-159 / 90-99 $\mathrm{mmHg}$ ) dan hipertensi tahap 2 (tekanan sistolik $160 \mathrm{mmHg}$ atau tekanan diastolik 100 $\mathrm{mmHg}$ ). Krisis hipertensi dapat diklasifikasikan menjadi hipertensi emergensi dan urgensi. Hipertensi biasanya selalu memiliki hubungan dengan kelainan aktivitas simpatik, meningkatkan resistensi pembuluh darah perifer (SVR) atau meningkat keduanya. Tapi penyebab paling umum dari hipertensi adalah meningkatkan resistensi pembuluh darah perifer. Pasien dengan hipertensi cenderung memiliki ketidakstabilan haemodinamik. Pemantauan terbaik untuk pasien dengan hipertensi adalah dengan menggunakan agen antihipertensi yang sesuai. Manajemen asuhan keperawatan pasien hipertensi akan menurunkan angka kesakitan dan kematian.
\end{abstract}

Kata kunci: krisis hipertensi, hipertensi emergensi, hipertensi urgensi

\begin{abstract}
Hypertension is a leading cause of death and become major risk factor for cardiac, cerebral, renal and vascular disease. Aggressive controlled hypertension will decrease complications due to the damage of end organs. The National Committee 7 (JNC 7) on prevention, detection, evaluation and treatment of high blood pressure 2003, degree of hypertension can be classified into pre-hypertension (120-139/8089), hypertension stage $1(140-159 / 90-99 \mathrm{mmHg}$ ) and hypertension stage 2 (systolic pressure $160 \mathrm{mmHg}$ or diastolic pressure $100 \mathrm{mmHg}$ ). Hypertensive crises can be classified into emergency hypertension and urgency hypertension. Usually hypertension always has association with abnormality of sympathetic activity, increasing the pheripheral vascular resistance (SVR) or increasing both of them. But the most common cause of hypertension is increasing the pheripheral vascular resistance. Patient with hypertension incline to have instability haemodinamic. The best monitoring for patient with hypertension is by using suitable antihypertensive agents. Excellent nursing care management of hypertension patients will decrease morbidity and mortality rate.
\end{abstract}

Keywords: hypertensive crises, hyspertensive emergencies, hypertensive urgency

\section{LATAR BELAKANG}

Hipertensi adalah penyakit yang umum dijumpai. Hipertensi yang tidak terkontrol yang dibiarkan lama akan mempercepat terjadinya arterosklerosis dan hipertensi sendiri merupakan faktor risiko mayor terjadinya penyakit-penyakit jantung, serebral, ginjal dan vaskuler. Pengendalian hipertensi yang agresif akan menurunkan komplikasi terjadinya infark miokardium, gagal jantung kongestif, stroke, gagal ginjal, penyakit oklusi perifer dan diseksi aorta, sehingga morbiditas dapat dikurangi.

Diperkirakan satu dari empat populasi dewasa di Amerika atau sekitar 60 juta individu dan hampir 1 milyar penduduk dunia menderita hipertensi, dengan mayoritas dari populasi ini mempunyai risiko yang tinggi untuk mendapatkan komplikasi 
kardiovaskuler. Data yang diperoleh dari Framingham Heart Study menyatakan bahwa prevalensi hipertensi tetap akan meningkat meskipun sudah dilakukan deteksi dini dengan dilakukan pengukuran tekanan darah secara teratur.

\section{Konsep Krisis Hipertensi}

Dikatakan krisis hipertensi jika tekanan darah meningkat, terutama peningkatan tekanan darah diastole. Tidak ada patokan yang absolut, tetapi apabila tekanan darah diastole berada dalam rentang 120-130 $\mathrm{mmHg}$, hal tersebut dapat menjadi dasar penentuan keadaaan krisis (Leong \& Manning, 2004). Pasien dengan hipertensi sistemik kronis dapat mentoleransi tekanan darah sistole yang lebih tinggi dibandingkan individu yang sebelumnya normotensif dan lebih mungkin mengalami hipertensi yang sifatnya urgensi dibandingkan emergensi. Halhal yang paling sering menimbulkan krisis hipertensi adalah antara lain karena penggunaan obat antihipertensi seperti clonidine, hiperaktivitas autonom, obat-obat penyakit kolagen-vaskuler, glomerulonefritis akut, cedera kepala, neoplasia seperti pheokromasitoma, preeklampsia dan eklampsia. Manifestasi klinis yang timbul adalah sesuai dengan target organ yang rusak akibat hipertensi ini (Wiryana, 2008). Berdasarkan ada tidaknya ancaman kerusakan target organ atau kerusakan target organ yang progresif, krisis hipertensi dapat dibedakan menjadi hipertensi emergensi dan urgensi (Leong \& Maning, 2004). Hipertensi emergensi adalah pasien dengan bukti adanya kerusakan target organ yang sedang terjadi atau akut (ensefalopati, perdarahan intra serebral, kegagalan ventrikel kiri akut dengan edema paru, unstable angina, diseksi aneurisme aorta, IMA, eklampsia, anemia hemolitik mikro angiopati atau insufisiensi renal) yang memerlukan intervensi farmakologi yang tepat untuk menurunkan tekana darah sistemik. Manifestasi klinis hipertensi urgensi antara lain: meningkatnya tekanan darah, sakit kepala yang parah, kecemasan, sesak napas (Sheps, 2009). Sedangkan manifestasi klinis dari hipertensi emergensi yaitu terdapat kerusakan organ, misalnya perubahan status mental seperti pada ensefalopati, stroke, gagal jantung, angina, edema paru, serangan jantung, aneurisma, eklampsi (Bryg, 2009). Patofisiologi hipertensi darurat belum diketahui secara pasti. Kegagalan autoregulasi normal dan kenaikan resistensi vaskuler sistemik (SVR) tiba-tiba biasanya awal dalam proses penyakit. Peningkatan SVR diperkirakan terjadi dari pelepasan vasokonstriktor humoral dari dinding pembuluh darah yang mengalami stres. Ketika tekanan meningkat dalam pembuluh darah akan memicu siklus kerusakan endotel mulai dari aktivasi lokal faktor pembekuan intravaskular, nekrosis fibrinoid pembuluh darah kecil, dan pelepasan lebih banyak vasokonstriktor. Jika proses ini tidak berhenti, siklus dari cedera vaskular lebih lanjut, iskemia jaringan, dan disfungsi autoregulatori terjadi kemudian. Presentasi klinis yang paling umum adalah hipertensi darurat infark serebral $(24,5 \%)$, edema paru $(22,5 \%)$, ensefalopati hipertensi $(16,3 \%)$, dan gagal jantung kongestif (12\%). Kurang presentasi umum meliputi pendarahan intrakranial, diseksi aorta, dan eklampsia.

\section{Sistem Saraf Pusat}

Serebral autoregulasi adalah kemampuan inheren dari vaskular otak untuk mempertahankan aliran darah serebral dengan konstan (CBF) di berbagai tekanan perfusi. Pasien dengan hipertensi kronis dapat mentoleransi lebih tinggi berarti tekanan arteri (MAP) sebelum mereka memiliki gangguan sistem autoregulasi. Namun, pasien tersebut juga mengalami peningkatan resistensi serebrovaskular dan lebih rentan terhadap iskemia serebral ketika aliran menurun, terutama jika tekanan darah menurun ke 
kisaran normal. Tekanan darah yang naik dengan cepat dapat menyebabkan hiperperfusi dan meningkatkan $\mathrm{CBF}$, yang dapat menyebabkan tekanan intrakranial meningkat dan edema serebral. Hipertensi ensefalopati merupakan salah satu manifestasi klinis edema serebral dan microhemorrhages terlihat dengan disfungsi dari autoregulasi otak dan ditandai oleh hipertensi, pemikiran berubah, dan papil edema.

\section{Sistem Kardiovaskular}

Hipertensi kronis menyebabkan peningkatan kekakuan arteri, peningkatan tekanan darah sistolik, dan tekanan nadi melebar. Faktor-faktor ini berperan untuk menurunkan tekanan perfusi koroner, meningkatkan konsumsi oksigen miokard, dan menyebabkan hipertrofi ventrikel kiri. Selama hipertensi emergensi, ventrikel kiri tidak mampu mengkompensasi kenaikan tahanan vaskuler akut sistemik. Hal ini mengarah ke gagal ventrikel kiri dan edema paru atau iskemia miokard.

\section{Ginjal}

Hipertensi kronis menyebabkan perubahan patologis pada arteri kecil ginjal. Arteri berkembang menjadi disfungsi endotel dan vasodilatasi terganggu, yang mengubah autoregulasi ginjal. Ketika sistem autoregulatori ginjal terganggu, tekanan intra glomerular mulai bervariasi secara langsung dengan tekanan arteri sistemik, sehingga menawarkan perlindungan untuk ginjal selama fluktuasi BP. Selama krisis hipertensi, ini dapat menyebabkan iskemia ginjal akut (Christy, 2010).

\section{Pengkajian}

Untuk mengetahui hipertensi emergensi harus ditanyakan riwayat kesehatan yang lalu termasuk obat-obatan apa yang pernah dikonsumsi sebelumnya. Untuk mengkaji kerusakan organ dapat dilakukan beberapa pemeriksaan diagnostik, antara lain pemeriksaan darah dan urine. Pada hipertensi emergensi, tujuan utama yaitu menurunkan tekanan darah dengan cepat melalui medikasi intravena untuk mencegah kerusakan organ lebih lanjut. Penatalaksanaan juga lebih dispesifikkan pada kerusakan organ yang mendasari (Bryg, 2009).

Ensefalopati jarang terjadi pada pasien dengan hipertensi kronis sampai tekanan darah diastole melebihi $150 \mathrm{mmHg}$ sedangkan pada wanita hamil yang mengalami hipertensi dapat mengalami tanda-tanda ensefalopati pada tekanan darah diastole $<100 \mathrm{mmHg}$. Sehingga walaupun tidak ada gejala, wanita hamil dengan tekanan darah diastole $>109$ mmHg dianggap sebagai hipertensi emergensi dan memerlukan terapi segera. Bila tekanan darah diturunkan secara cepat akan terjadi iskemia koroner akut, sehingga MAP diturunkan sekitar $20 \%$ dalam 1 jam pertama, selanjutnya pelan-pelan diturunkan sampai 160/110 selama 2-6 jam. Tanda-tanda penurunan tekanan darah ditoleransi dengan baik adalah selama fase ini tidak ada tandatanda hipoperfusi target organ. Hipertensi urgensi adalah situasi dimana tekanan darah meningkat tinggi secara akut, namun tidak ada bukti adanya kerusakan target organ. Gejala yang timbul dapat berupa sakit kepala, epitaksis atau ansietas. Penurunan tekanan darah yang segera tidak merupakan indikasi dan pada banyak kasus dapat ditangani dengan kombinasi antihipertensi oral bertahap dalam beberapa hari. Dikarenakan kita tidak bisa mengukur autoregulasi serebral sehingga ada beberapa acuan yang sebaiknya diperhatikan, yaitu:

- Penurunan MAP sampai dengan 25\% adalah batas bawah yang maksimal yang dianjurkan untuk penderita hipertensi.

- Penurunan MAP sebesar 55\% akan menyebabkan timbulnya gejala hipoperfusi otak. 
- Terapi dengan antihipertensi secara signifikan menurunkan angka kejadian stroke.

- Pengaruh hipertensi kronis terhadap autoregulasi ginjal, kurang lebih sama dengan yang terjadi pada serebral (Wiryana, 2008).

\section{Perawatan}

Pasien dengan tekanan darah yang tinggi dan disertai kerusakan organ secara akut (encephalopathy, myocardial infarction, unstable angina, pulmonary edema, eclampsia, stroke, head trauma, life-threatening arterial bleeding, or aortic dissection) membutuhkan perawatan di rumah sakit dan terapi obat secara parenteral. Pasien dengan tekanan darah tinggi tanpa disertai kerusakan organ dapat berobat jalan dengan kombinasi terapi obat oral antihipertensi (JNC, 2003). Berikut ini ada beberapa contoh sebagai dasar pemilihan obat yang akan digunakan:
- Beta-adrenergik blockade: digunakan tunggal atau tambahan pada pasien dengan fungsi ventrikuler yang masih baik dan dikontra indikasikan pada bronkospastik.

- Nicardipine: digunakan pada pasien dengan penyakit bronkospastik.

- Nifedipine: refleks takikardia setelah pemberian sublingual sering dihubungkan dengan iskemia miokard dan antihipertensi yang mempunyai onset yang lambat.

- $\quad$ Nitroprusside: onset cepat dan efektif untuk terapi intra operatif pada hipertensi sedang sampai berat.

- Nitrogliserin: mungkin kurang efektif, namun bisa digunakan sebagai terapi atau pencegahan iskemia miokard.

- Fenoldopam: dapat digunakan untuk mempertahankan atau menjaga fungsi ginjal.

- Hydralazine: bisa menjaga kestabilan tekanan darah, namun obat ini juga punya onset yang lambat sehingga menyebabkan timbulnya respon takikardia (Wiryana, 2008).

Tabel 1. Golongan dan efek obat antihipertensi (Wiryana, 2008)

\begin{tabular}{|c|c|c|c|c|}
\hline Golongan Obat & Preload & Afterload & HR & Kontraktilitas \\
\hline Vasodilator & $\sqrt{2}$ & $\sqrt{2}$ & $\widehat{\tau}$ & ए \\
\hline channel & $\Leftrightarrow$ & I] & ] & $\sqrt{2}$ \\
\hline blocker & & & & \\
\hline ACE inhibitor & ת & $\sqrt{2}$ & $\sqrt{3}$ & ૫ \\
\hline Beta blocker & 凹 & ૫ & ] & ] \\
\hline
\end{tabular}

Pemantauan hemodinamik dan status kardiovaskular yang intensif diperlukan selama merawat klien dengan hipertensi darurat dan urgensi. Perawat dapat memonitor tanda-tanda vital setiap 5 menit jika tekanan darah berubah atau masih belum stabil. Dan pemeriksaan tanda vital setiap 15 atau 30 menit dapat dilakukan jika situasi lebih stabil.

\section{KESIMPULAN DAN SARAN}

Hipertensi adalah penyakit yang umum dijumpai, dengan angka penderita yang cukup tinggi. Hipertensi sendiri merupakan faktor risiko mayor yang bisa menyebabkan terjadinya komplikasi seperti penyakitjantung, serebral, ginjal dan vaskuler.

Mengingat tingginya angka kejadian dan komplikasi yang bisa ditimbulkan oleh penyakit hipertensi ini, maka perlu adanya pemahaman perawat dalam manajemen pasien dengan krisis hipertensi untuk 
meminimalkan terjadinya komplikasi. Hal ini harus diantisipasi dengan perlunya pemahaman pengetahuan farmakologi obatobat yang digunakan, baik obat-obatan antihipertensi. Dengan manajemen asuhan keperawatan yang benar terhadap penderitapenderita hipertensi diharapkan bisa menurunkan atau meminimalkan angka morbiditas maupun mortalitas.

\section{DAFTAR PUSTAKA}

Bryg, R.J. 2009. High Blood Pressure and Hypertensive Crisis. http:// www.webmd.com/hypertension-highblood-pressure/guide/hypertensivecrisis. Diakses pada 1 Juli 2010.

Brunner \& Suddarth. 2000. Brunner \& Suddarth Textbook of Medical Surgical Nursing. New York: McGraw-Hill.

Leong, B. \& Manning, P. 2004. Hypertensive Crises in the Book: Guide to The Essentials in Emergency Medicine. Singapore: McGraw-Hill Education.

Sheps, S.G. 2009. High Blood Pressure (Hypertension). http:// www.mayoclinic.com/health/ hypertensive-crisis/AN00626. Diakses pada 1 Juli 2010.

The Seventh Report of Joint National Committee (JNC) on Prevention, Detection, Evaluation, and Treatment of High Blood Pressure. NIH publication No 03-5233, December 2003.

Wiryana, M. 2008. Manajemen Perioperatif Pada Hipertensi. Jurnal Penyakit Dalam Volume 6 Nomor 2 Christy, Hopkins. 2010. Hypertensive Emergencies. http:/ /as.medscape.com/html.ng/ Diakses pada 1 Juli 2010.

Moser, M., Joseph, L., Izzo, J., Bisognano, J. 2006. Hypertensive Emergencies. The Journal of Clnical Hypertension. Volume 8 No. 4. 